\title{
The Anomalous Position of Trustee to Debenture In Nigeria
}

\author{
KunleAina* \\ Faculty of Law, University of Ibadan, Nigeria.
}

\section{Introduction}

The Company is empowered by Law to raise money for its undertakings by either selling its shares or by direct debt finance; this is by approaching the financial institutions for loans to pursue their business plans. The most accessible form of external finance for companies is a loan from a financial institution. The loan capital markets represent an important feature on the corporate fiancé landscape. ${ }^{1}$ Whilst it may be easy to raise debt capital from the Banks, or other financial institution, they will not wish to take risks, and so will insist on taking a form of security for the loan. The indebtedness of the company to the financial institution is generally acknowledged by way of debenture. In some cases, the company may wish to raise a large capital by simply soliciting the funds from the general public. This may be similar to creating securities in form of shares. The company will simply create a form of security instrument known as debenture stock, this enables many investors to be able to invest in the securities at the same time and on the same terms. The sale of the securities iseffected mainly through the stock market or exchanges specified by the agreements and backed by law. The debenture trust deed sets out the voting rights and meetings of the debenture holders. A very important issue here is that the company appoints a trustee under the Trust Deed who acts as intermediary between the company and the debenture holders. The trustees are the legally recognized managers of the funds and representative of the debenture holders. The trustee not only represents the interest of the debenture holders but also serve for administrative ease and convenience. As the financial institution will now deal with the trustees only, and the trustees represents the interests of the debenture holders, the debenture holders deal with the company through the trustees.

The loans are therefore aggregated sums advanced to the company in a lump sum by the trustees. The investors subscribe to the debenture stock or loan stock out of the fund, and the stock forms part of the securities of the company. In this circumstance, the lenders will require security for their money advanced to the company, and it will require that the company charge part of or all their properties as security for the loan.

This paper will examine the legal regime for the creation and regulation of debenturesgenerally, the trust deed, the role of the trustees and the protection of debenture holders rights, as failure will lead to disastrous affects, not only to the debenture holders, but also lead to loss of confidence in the debt capital market of the Nation.

\section{Power to Borrow Money by Companies.}

Every company is empowered to borrow money in Nigeria, Section 166 of the Companies and Allied Matter Act $2004^{2}$ provides as follows:-

A company may borrow money for the purpose of its business or objects and may mortgage or charge its undertaking, property and uncalled capital, or any part thereof, and issue debentures, debenture stock and other securities whether outright or as security for any debt, liability or obligation of the company or of any third party.

However, under the common law, only a trading company has the power without any further authority under the memorandum and Articles of Association to borrow money pursuant to its stated objects. The power to borrow money is an incidental power in furtherance to the objects. ${ }^{3}$ In the case of a non-trading company, there must be express provision in the memorandum and Articles of Association permitting the company to borrow money. The common law distinction between a non-trading company and a trading company seems illogical. Every limited liability company is incorporated for the purpose of profit. All other companies incorporated as a nonprofit organization are registered as company limited by guarantee ${ }^{4}$ or registered under part $\mathrm{C}$ of the CAMA 2004. The distinction between the power of company to borrow money is no longer relevant as Section 38 of the CAMA 2004 now provides that, subject to the provisions of the company's memorandum or any enactment otherwise provides, every company shall, for the furtherance of its authorized business or objects, have all the powers of a natural person of full capacity.

\footnotetext{
*Senior Lecturer, Faculty of Law, University of Ibadan, Nigeria.

${ }^{1}$ Dignam A and Lowry J. 2009.Company law London; Oxford University Press. 85

${ }^{2}$ Cap. C20, Laws of Federation 2004 (hereinafter called CAMA 2004)

${ }^{3}$ Bryan v Metropolitan Co. (1858) 3 D.G. \& J. 123, see also General Auction Estate Co. v Smith (1891) 3 Ch. 432

${ }^{4}$ Section 26 of CAMA 2004
} 


\section{Legal Nature of Debentures.}

The 'Debenture' is a contractual relationship between creditor and a debtor, if, which is the case in most debentures, coupled with a charge on the properties and assets of the company it may be classified as a mortgage transaction as well. The difference between the debenture holder and that of a shareholder is that the debenture holder is a creditor with interests and rights against the company. However, the position of the debenture holder may be closely associated with that of the shareholder. This is because, the debenture holder legally subject to the provisions of the articles of association, may also be allowed to;

(1) Appoint a director for the company,

(2) Share in the profits (though in his own case, whether profits are made or not or whether the company declares dividend or not)

(3) Repayment at a premium

(4) Attend meetings; vote at meetings but not during meetings of extraordinary resolution to convert debentures into equity shares which he will be holding as 'equity security' and when he exercises the right, will become an 'equity security'. Where the debenture is secured by a floating charge he will have an equitable interest in the company different from that of the shareholder. ${ }^{5}$

Generally, "debenture" is applied not to the indebtedness itself but to the document evidencing it. ${ }^{6}$.

Because of the distinction between securities whose holders are members, and securities whose holders are outside creditors, ${ }^{7}$ the rules relating to the raising and maintenance of capital applies only to the former, subject to the exceptions already mentioned, shares impose a liability, on the holder to pay in cash or in kind than nominal value, and while the company is a going concern, the nominal value or the capital of the company cannot be reduced by repayment nor can the shareholders be paid any return on their investments except out of profits. ${ }^{8}$ None of these rules applies to the debenture holders, they may be paid out of the company's capital, the shares cannot be sold at a discount, and the debentures may be issued at a discount. Theoretically, the debenture holders are not interested in the company except that they are happy that the company continues to be healthy for the purpose of their investments only. ${ }^{9}$ In the event of bankruptcy, the debenture holders has a right to be paid their investments whilst the shareholders have nothing to collect, in fact, the receiver, may still call up allotted and unpaid capital. ${ }^{10}$

\section{Debenture Trust Deed}

\section{Issues in a series and parripassu clauses:-}

Where debentures are issued in series, thedebentures must contain a parripassu (i.e equality) clause, if this is not done, they rank according to the date of the issue or if all issued the same day, by their numbering.

The debentures of this series are all to rank parripassu in point of charge without any preference or priority one over another, ${ }^{11}$ Whether any company offers debentures to the general public for subscription or purchase, it must execute a debenture trust deed in respect of the offer and the trust deed must be executed between the company and the trustee for the debenture though not a subscriber, is the person recognized by law as the legal owner of the entire issue, and he is the one that represents all the debenture holders while he holds the legal interest to the debenture and the investors are the beneficiaries, ${ }^{12}$ in cases where the debenture trust is classified into different classes no single debenture trust deed can cover more than one class of debentures.

The debentures will belong to different classes if different rights attach to them in respect of:-

(a) The rate of or dates for payments of interest;

(b) The dates when, or the installments by which, the principal of the debenture shall be unpaid, unless the difference is solely that the class of debentures shall be repaid during the stated period of time and particular debenture may be repaid at different dates during that period

(c) According to selections made by the company or by drawings, ballot or otherwise,

(d) Any right to subscribe for or convert the debentures into shares in or other debentures of the company or any other company, or

(e) The powers of the debenture holders to realize any security.

\footnotetext{
${ }^{5}$ Section 186(2) CAMA 2004. The trustee is empowered to safeguard the right of the debenture holders and to exercise the rights, powers and discretions conferred upon them by the trust deed.

${ }^{6}$ Lemon v Austin Friers Investment Trust Ltd (1926) Ch.1.

${ }^{7}$ Davies P. 2008. Gower and Davies principles of modern company Law. $8^{\text {th }}$ ed. London, Sweet and Maxwell.p. 1141.

${ }^{8}$ Omotola J. 2006. The Laws of secured credit.Ibadan; Evans Brothers (Nigeria Publishers) Ltd. p. 163.

${ }^{9}$ Morse G. Charlesworth and Morse Company Law. $15^{\text {th }}$ ed. London; Sweet and Maxwell. 613.

${ }^{10}$ Morey M. 1988.Bondholders and Stock holders.Journal of Corporation Law. 13. 20.

${ }^{11}$ Farrar J. 1986. Company Law. London; Butterworths, 210

${ }^{12}$ Pennington .R. op citCh.12
} 
Debentures do not belong to the same class, if they do not rank equally for payments when the security invested in the debenture holders under the trust deed is realised. ${ }^{13}$ Debenture stock holders unlike debenture holders are not creditors of the company. Thus in Re Dunderland Iron Ore Co. Ltd. ${ }^{14}$ it was held that the holder of the debenture stock secured by a trust deed could not present a petition for the winding up of the company since he was not a creditor. The trustees are the creditors for the whole debenture debt; and the stock holder is an equitable beneficiary of the trust, but by suing the trustees on behalf of himself and the other debenture holders to compel the trustees to exercise their remedies against the company, he can indirectly enforce the same remedies against the company as the holder of a single debenture can enforce directly.

The law requires that every debenture trust deed must include the following terms:-

(a) The maximum sum which the company may raise by issuing debentures of the same class.

(b) Maximum discount which may be allowed on the issue or re-issue of the debentures and the maximum premium of which the debentures may be made redeemable

(c) The nature of any assets over which a mortgage, charge or security is created by the trust deed in favour of the trustee for the benefit of the debenture holders, the specific identity of the assets ${ }^{15}$

(d) If the charge is to be created in favour of a third party other than the trustee to the debenture, the nature and identity of the properties must be stated.

(e) Whether the company will create any mortgage or charge or security in favour of some and not all the debenture holders.

(f) Any prohibition or restriction on the power of the company to issue debenture or to create mortgages, charges or nay security or any of its assets ranking in priority to, or equally with the debentures issued under the trust deed.

(g) Whether the company shall have power to acquire debenture issued under the trust deed before the date of their redemption and to re-issue the debentures;

(h) The rate of and the dates on which interest on the debentures issued under the trust deed shall be paid and the manner in which payment may be made.

(i) Provision for meetings of debenture holders.

(j) Power of the trustees to appoint a receiver when the security becomes enforceable.

(k) Whether the rights of the debenture holders may be altered or abrogated, and if the conditions that must be fulfilled, and the procedure to follow to effect such an alteration or abrogation.

(1) The amount or rate of remuneration to be paid to the trustee and the period for which it shall be paid, and whether it shall be paid in priority to the principal, interest and costs in respect of debentures issued under the trust deed.

(m) The debenture must state clearly whether it is secured or not ${ }^{16}$

The provisions of Section 185 of CAMA 2004 is certainly not exhaustive as the Lawmerely gave an indication and sketch of what is expected of a standard debenture trust deed, the contracting parties are free to add or include terms to accommodate their peculiar circumstances.

The advantage and uses of the trust deed are:

1. It enables a legal or equitable mortgage on specific assets of the company to be created;

the deeds of property charged under the debenture is held by trustees, and where there is a legal mortgage, the legal estate is vested in them. It could not be vested in hundreds or possibly thousands of debenture holders because, since the property legislations ${ }^{17}$ the legal estate cannot be vested in more than four persons.

2. Priorities;

A mortgage in general terms, ranks in the order of its creation, so without a trust deed, in an issue to the public, the holder of the first certificate to be issued would rank in front of the second and so on. Holder number one would be entitled to payment from the company's assets in full before the second certificate holder gets anything. Certificate holder, say 1,000 might get nothing if the company's assets were insufficient under the trust deed the trustees have the charge and can sell the company's assets and distribute the proceed equally so that all the stock holders get the same amount even if it is not a payment in full. Distribution is parripassu which is a term commonly used of this procedure.

3 .The interests of the debenture holders are safeguarded by the employment of professional corporation or by a small number of expert trustees than they would be left to the debenture holders themselves. The holders are often widely dispersed and often lack the knowledge required to safeguard their interests' properly. Trustees

\footnotetext{
${ }^{13}$ Section 183 CAMA 2004.

${ }^{14}$ Dignam A and Lowry J. 2009.Company Law. $5^{\text {th }}$ ed. London: Oxford University Press. P. 84.

${ }^{15}$ Section 183 CAMA 2004.

${ }^{16}$ (1909) 1 Ch. 446.

${ }^{17}$ If they are not subject of floating charge.
} 
duty include calling of meetings of debenture holders to inform them of matters of particular concern to them and their interest.

4. The trust deed usually gives the trustees power to sell the property charged- the trust deed and the relevant documents of the charged properties are normally kept with the trustees to the debenture, they as the legal owners have the power to appoint an administrative receiver should the company default in the payment of the interest or repayment of the principal sums borrowed without the intervention of the court.

5. The trust deed will usually give the trustees the power to see that the security is properly maintained and repaired and insured.

\section{The legalposition of the Trustees to the debenture}

The position of the debenture trustee is a very delicate and sensitive position. He is the only legal owner of the debenture and he represents the debenture holders in all transactions with the company, ${ }^{18}$ it is an important use of the trust today in connection with the issuance of corporate obligations. The trust device has become the standard means of giving to the holders of such obligations the security of a mortgage or pledge of property. The typical transaction is the issuance by a company of debentures secured by mortgage on physical properties as well as a tangibles and receivable as security for the issue of debentures. ${ }^{19}$

Historically, use of the trust in connection with the issuance of securities was first done approximately around the year $1830^{20}$ most of the early indentures were given to secure rail road issues ${ }^{21}$. The trustees were one or more individuals ${ }^{22}$ who were frequently officer of or otherwise connected with the issuer. ${ }^{23}$ By 1860 the use of a trustee for debenture holders apparently had become common, ${ }^{24}$ and in 1873 , in dealing with a rail road mortgage which made no provision for a trustee, the United States Supreme Court noted this as a departure from "ordinary practice" 25

Increasingly, it may be observed over the years ofthe gradual development of the debenture as a tool for commercial transactions, two major changes can be discovered, one is the use of intangibles as security, the second, is the increasing use of the corporate trustee. Although, the individual trustee may still be found as trustee for debenture holders but he has been largely displaced by the corporate trustee in America and the United Kingdom. ${ }^{26}$ The use of corporate trustees is a factor to be taken into account in determining the dutieswhich should be placed upon trustees for debenture holders. ${ }^{27}$

\section{Qualifications for Trustee for Debenture}

As far back as 1936, in the USA, a detailed investigation of "Trustees Under Indenture" was made by the Securities and Exchange Commission, culminating in a report issued in 1936. The recommendations contained in the report resulted in the passage of the Trust indenture Act of $1939{ }^{28}$ The Act had recognized the very delicate position of the trustee under a debenture deed, and had made provisions to ensure that only corporate trustees should be registered under the Act as trustees for debenture, and secondly, any applicant for registration as trustees of the debenture is disqualified by various conflicting interests provisions or unless the debenture shall contain certain detailed provisions.

Under English Law, the trustee to the debenture had always been a trust corporation ${ }^{29}$ and this is the general position all over the world. ${ }^{30}$ For instance the Indian position ${ }^{31}$ prescribed that no person shall be entitled to act as Debenture Trustee unless he is either a scheduled bank carrying on commercial activity or a public institution within the meaning of Section $4 \mathrm{~A}^{32}$ of the act or an insurance company or a body corporate. ${ }^{33}$ The

\footnotetext{
${ }^{18}$ See generally, section 184 CAMA 2004.

${ }^{19}$ Section 185 CAMA 2004.

${ }^{20}$ Conveyance Act of 1881, and Property and Conveyance Law of 1959.

${ }^{21}$ See Davies P. op. cit. page 1142 .

${ }^{22}$ The nature, value and extent of the security will depend on the available assets of the company as well as the value of the debt proposed to be raised form the subscribers.

${ }^{23}$ Smith has stated years ago that the earliest use was in 1830, when the Morris Canal and Banking Company executed a mortgage to one Willinik as "agent and trustee of the several subscribers".Smith A. 1927. A forgotten chapter in the early history of the corporation trust Deed. 61 American Law Review. 900. 904, Willink v Morris Coral of Banking Co. (1843) 4 N.J. eq. 377.

${ }^{24}$ Allen v MontgomerY R.R. (1847) 11 AL 437, Chapin v Verment\& Mass. (1857) 74 mass 575.

${ }_{25}$.for instance, a mortgage executed by the Baltimore and Ohio Railroad in 18465 appointed the President of the Railroad and his successors as trustee, see Stetson R. 1922 .Preparation of corporate bonds, mortgage, collateral trusts and debenture indentures in Some legal phases of corporate financing, reorganization and regulation. 1. 12. 13.

${ }^{26}$ Ashurst v Montour Iron Co. (1860) 35 pa. 30.

${ }^{27}$ Nashville \& Decatur R.R v Orr.(1873) 18 Wall .471 US

${ }^{28}$ Smith A. op. cit.

${ }^{29}$ Palmer G. E. 1941. Trusteeship under the trust indenture.Columbia Law Review. 41.2. 193-200.

${ }^{30}$ See the Securities and Exchange Commission report on the study and investigation of the work, activities personnel and functions of protective and reorganization committees, part iii, committees for the Holders of Real Estate Bonds (June. 1936).

${ }^{31}$ Bank B. 1938. Indenture securities and the Barkley Bill... Yale Law Journal. 48. 533.

${ }_{2}^{2}$ Davies P. 2008. Gower and Davies Company Law. $8^{\text {th }}$ ed. London :Sweet and Maxwell P. 1142.

${ }^{33}$ See Section 74, Companies Act 1965 (Revised 1973) Malaysia.
} 
major reason why individuals may not effectively carry out the duties of the trustee for the debenture is obvious, the enormous administrative duties, keeping tabs on the company securities and ensuring proper representation of the debenture holders will entail appointing a competent corporate entity and not an individual. In fixing the qualifications, the ${ }^{34}$ Securities and Exchange Board (debenture trustee) regulations 1993, Section 6 thereof, provides that in considering granting a license to persons eligible under Section 7 of the regulation ${ }^{35}$, The Board is enjoined to consider the infrastructure like office space, equipments and manpower to effectively discharge his activities and experience, with least two persons in the employment of the applicant who had experience in matters which are relevant to a debenture trustees etc.

In Nigeria, the Companies and Allied Matters Act did not provide for the qualification of the debenture trustee but only made provisions for persons that are disqualified from being appointed as a Debenture Trustee. This is unfortunate and a great omission in the Law. By not specifying the categories of those who are qualified to be appointed trustees for debenture, the law will thereby be permitting any individual who is not otherwise disqualified under Section 187 of the Act. The most important disqualification provision is as contained in Section 187(1) of the Act which states that a person is not qualified for appointment as a trustee of a debenture trust deed if he is:

(a) an officer or an employee of the company which issues debenture covered by the trust deed or of a company in the same group of companies as the company so issuing debenture, ${ }^{36}$

Other disqualified persons are:

(1) person less than 18 years of age

(2) person of unsound mind and who has been so found by a Court in Nigeria

(3) undischarged bankrupt

(4) person disqualified from being a Director under Section 257 of the Act

(5) substantial shareholder ${ }^{37}$

It follows that apart from the general provisions in Section 187, anybody, whether individual or corporate organisation ${ }^{38}$ may act as trustee to debenture. This is absolutely against the general trend all over the world. The modalities for an individual acting as a trustee to debentures is not only an anomaly but dangerous, and I believe that the law ought to be amended by making provisions that only a company registered as a trust company that specialise only in trustee duties, with infrastructural backup.

Further due to the very important duties of the trustee, the Nigerian Law ought to adopt the position in India, and make provision for any applicant for the certificate to make a deposit of cash funds with the Central Bank of Nigeria as security for its good behavior, further, there should be a special law, that regulates and prescribe the, legal duties of the trustees, and a special regulator to regulate their activities. The Investment and Securities Act 2007 merely covers the registration of Capital Market Operators and there is nothing regulating the registration of trustees for debentures probably because the Nigerian debt market is still largely undeveloped.

\section{Appointment}

The trustee to debenture holders are generally appointed under the Trust Deed setting up the debenture.$^{39}$ The pertinent question is that, who is responsible for drawing up the debenture trust deed? It is important to understand the practical nature of the arrangement between the issuer (the company) the trustee and the debenture holder. The whole arrangement is reflected by the trust deed, which is essentially a bilateral contract between the issuer and the trustee providing for the issue of the debentures. The debenture holder is never a party. ${ }^{40}$ The trustee ordinarily will be appointed by the company issuing the debenture the debenture trust deed is also drawn up by the Solicitors for the issuer, sometimes in conjunction with the issuing house employed to market the securities in the open market. The trustee may only make inputs in respect to adding changes to protect them from liability and eventually executed between the trustee (who is the issuer's nominee) and the issuing company itself. The trustee and the company therefore have the opportunity to insert various clauses and covenants, called exculpatory provisions to absolve them of any wrong doing. The great disadvantage is that the debenture holders who are the real investors have no say in the appointment of the trustees or the inputs made in the debenture trust deeds. ${ }^{41}$ In most of the issues in Nigeria, the Banks also have a

\footnotetext{
${ }^{34}$ Section 117 B of Securities and Exchange SEBI (Debenture Trustee) Regulations, 1993.

${ }^{35}$ Section 4 A of the Act.

${ }^{36}$ It is necessary that such an entity should have capital adequate of net worth of one crore of Rupees and have been licenced by SEBI to act as Debenture Trustee.

${ }^{37}$ Section 6 of Securities and Exchange Board of India (DEBENTURE TRUSTEES) REGULATION, 1993.

${ }^{38}$ Mentioned above.

${ }^{39}$ Section 187(1)(a) CAMA 2004.

${ }^{40}$ See Section 95 CAMA 2004.

${ }^{41}$ It may seems that the Act does not directly recognize trust companiess acting as trustee to debentures in Nigeria.
} 
trustee department which handles all the trustee debenture issues for the Bank. In effect, the fate of the subscribers is in the hands of the company absolutely especially where the Bank is the one issuing the debenture. ${ }^{42}$ Others will naturally appoint agents close to them, and who will do their biddings. In Nigeria, the only safeguard against this is Section 187(1)(a) CAMA 2004 which provided that the employee or officer of a company which issues debenture covered by the trust deed of a company in the same group of companies as the company so issuing the debentures are disqualified from being appointed as a trustee of the debenture trust,. The problem is that the Law does not include subsidiaries, or companies or entitles in which the issuer may have interest either substantial or minor. Because the Section is limited to individuals appointment as trustee, the door is only open for series of conflict issues involving corporate entities, for instance under the Securities and Exchange Board of India (Debenture trustees) Regulations, 1993 (SEBI debenture trustees regulations'. Section 7 of the Act specifically provides for eligibility for registration as a corporate debenture trustee, and it does not include or envisage an individual trustee ${ }^{43}$, so that the issue of being employee or officer of the trustee does not arise at all.

The trustees to the debenture trust are the only legally recognized organ under the trust debenture deed representing the debenture holding, where the only document which specifies the rights and duties of the trustees are drawn up by them the tendency is for them to ensure that their liability for any breach of duty is excused.

\section{Liability of trustees for debenture holders.}

The corporate trust deed has become one of the largest and most complex contracts used in corporate Law. The relationship between the issuer (company), trustee and debenture holders is entirely the product of the agreement. This is in marked contrast to the relationship between the issuer and its shareholders, which is today governed largely by statute. ${ }^{44}$ The provisions created by contract are the "constant documents' of the securities to be issued. They regulate the security, the title constituting the debenture holders claim. They are however constituted by the rules made by the company itself. However, even with the admission that the rules or terms are dictated by the company, the trustee still has a role to play jointly with the company. Although issued on the decision of the company debentures must be certified by the trustee, who acts with the company (but only in strict compliance with the trust deed. In so acting the trustee authenticates the debentures. The debenture holder thus relies solely on the competence of the trustee that the debenture complies with and reflects truly the terms attaching to that class of securities issued by the company. ${ }^{45}$

From the point of view of debenture holders their rights are limited to those defined in the trust deed. The Act had not helped matters. ${ }^{46}$ By buying the debenture in the market place or by lending money evidenced by a debenture, they become creditors holding a security and accepting as a term of such security that:

(i) initially all rights to enforce its payment are vested in the trustee

(ii) should the trustees fail to act, the debenture holders may force the trustee to sue but only on posting security and with the approval of the three quarters majority of the entire debenture holders

(iii) In the alternative and where the trustee fails to act, the debenture holders may sue to compel the trustee to act or they may act indirectly in the name of the trustee. In all events such proceedings must be for the benefit of the debenture holders.

Section $186(2)^{47}$ specifically provides as follows:-

It shall be the duty of such trustees to safeguard the rights of the debenture holders and, on behalf of and for the benefit of all debenture holders, toexercise the rights, powers and discretions conferred upon them by the trust deed.

The charges securing the debenture are to be created in favour of the debenture holders by vesting them in the trustees. ${ }^{48}$ The Act also provides that any provision contained in the trust deed or any contract with the holders of debentures secured by a trust deed shall be void in so far as it would have the effect of exempting a trustee thereof from liability, or indemnifying him against liability for any breach of trust or failure to show the degree of care and skill required of him as trustee having regard to the powers, authorities or discretion's conferred on him by the trust deed. ${ }^{49}$ No specific degree of care and skill is required under the CAMA.

A debenture holder or the Commission may apply to the court to remove any trustee from his office if they can prove that the trustee has interests which conflict with or may conflict with those of the debenture

\footnotetext{
${ }^{42}$ See Section 186 CAMA 2004.

${ }^{43}$ Chaxton J. B. 1997. The corporate Trust Deed under Quebec Law: Article 2692 of the Civil Code of Quebec. McgillLawJournal/Revue De droit de McGill. 42. 797-861.

${ }^{44}$ Posner L. liability of the Trustee under the corporate indenture.Harvard Law Review. 42. 198.200

${ }^{45}$ If the issuer is a banker or financial institution.

${ }^{46}$ See generally Sections 6A, 7 and 7 A of SEBI (Indenture Regulations) 1993 India.

${ }^{47}$ See the Companies Act of various jurisdictions.

${ }^{48}$ Claxton J.B. op cit p. 807.

${ }^{49}$ Section 188 CAMA 2004.
} 
holders or that for any reason it is undesirable that such trustee should continue to act. ${ }^{50}$ This is a laudable provision that may seem to protect the debenture holders, and prevent the trustees from abusing their position.

However, the true position is that it is not likely that any trustee to a debenture deed will ever be caught under any of these provisions. This is because the Law does not prohibit the inclusion of provisions in the trust deed which excludes from liability the trustee for any act or omission in the course of the trusteeship. It is common for instance to include a clause in the debenture thus:-

The trustee shall not be answerable or responsible to anyone for any error of judgment nor for any act done or steps taken or omitted or demand made or with-held by it in good faith, nor for any mistake of fact or Law, nor foranything whatever in connection with this trust, except willful breach of trust. ${ }^{51}$

This type of clause exempting the trustee from liability is very common and Section 188(1) CAMA 2004 will seem to nullify them wherever they exist and sought to be relied upon. The problem is that the very degree of care expected of the trustee is not explained in the Act. While Ware ${ }^{52}$ argues that there seems to be little logic in holding the trustee responsible for such things as:

(1) misconduct of agents employed in good faith,

(2) verification of payment of taxes or insurance provisions,

(3) registration of security,

(4) verification of the title of the mortgagor.

The avowed three primary purposes of the Trustee Indenture Act of 1939 (USA) are:

(a) to provide full and fair disclosure throughout the life of the securities.

(b) To provide machinery whereby such continuing disclosure may be made to the security holders and whereby they may get together for the protection of their own interest,

(c) To ensure that the security holders will have the service of a disinterested indenture trustee and that such trustee will conform to the high standard of conduct now observed by the more conscientious trust institutions. ${ }^{53}$

Looking at the array of clauses which are particular and specific in form and directly linked with their duties, whether a single general provision in the Law can completely void such clauses is yet to be determined. What is the specific and general purpose of the Law in Nigeria on the duty of the trustees and steps and provisions within the Law to check them? The only provision in the Law on the duty of the trustee ${ }^{54}$ also included provisions for the release of the trustee in the event of his breach of trust. The majority (three quarters) of the debenture holders may meet and resolve to release the trustee from his liability. This can be done in the debenture trust deed or separately before the giving of the release, or an agreement by the majority (three quarters) of the members in a meeting called for the purpose ${ }^{55}$. The practical effect is to call the meetings, put forward such a proposal before the debenture holders at the onset of the debenture, and the debenture holders are most likely going to ratify such proposals. ${ }^{56}$

The first public investigation of the matter in Great Britain was undertaken by the Cohen Committee ${ }^{57}$ which submitted its report in 1945 . Evidence was given before the committee stating that, unlike the S.E.C. findings in the U.S., the protection provisions in the U.K trust indentures had not resulted in passive trusteeship and that therefore the U.K security holders had not suffered by reason of these provisions. The committee outlined the duties of the trustee in Britain as threefold,

(1) taking charge of any documents of title representing the security for the debentures,

(2) protecting the interest of the debenture holders, if and when the trustees attention is called to any breach by the company of its obligations,

(3) appointing a receiver when the power of sale arises in the events defined in the instrument of charge ${ }^{58}$

The Committee was concerned with the decision in Re City Equitable Fire Insurance Company ${ }^{59}$ which exonerates trustee unless he had truly committed a wrongful act; they recommended a prohibition which was modified in the Companies Act $1948^{60}$. This was the same provision still retained in the current Nigerian

\footnotetext{
${ }^{50}$ CAMA 2004.

${ }_{52}^{51}$ Section 186(3) CAMA 2004.

${ }^{52}$ Section 186(4) CAMA 2004.

${ }^{53}$ Section 186(5) CAMA 2004

${ }^{54}$ See for illustrations, Palmers company precedents, also Mullin and Davies, 1962 Canadian Corporation precedents..

${ }^{55}$ Ware J.G. 1968. The role of Trustees under trust indentures..

${ }^{56}$ Miller.R, Trust indenture Act of1939. Cornell Law Quarterly 25.105.

${ }^{57}$ Section 186.CAMA 2004.

${ }^{58}$ Section 188(2) CAMA 2004

${ }^{59}$ (1925) Ch. 407 ;GeorgeE.P trusteeship under the trust indenture..Columbia Law Review.41 193. 208.

${ }^{60}$ Cohen Committee Report.
} 
Legislation. ${ }^{61}$ The committee also cautioned trustees not to embark on any transaction with a risk of personal conflict of interest, but they did not make any recommendationfor legislation on this. This mild approach by the Cohen Committee had been critiqued.Gower ${ }^{62}$ favours the American approach which would make trustees for debenture holders really active supervisors instead of mechanical book keeping agencies. He critisises the Cohen Committee for not doing anything about the position though they expressed dissatisfaction. The Jenkins Report ${ }^{63}$ rejected adopting a model debenture trust deed, they are of the view that "no two cases are ever alike and the provision of a statutory form would only encourage drafting by reference and might lead to error and confusion". The Jenkins Report however recommended more disclosure to debenture holders (prospectus, registration, balance sheet and reports of documents) and provided rules for meetings of holders on the same lines as shareholders meetings. The current position in England ${ }^{64}$ is the very same position in the Nigerian Section 188, which in the opinion of Ware 'has not been extensive enough'. Davies, ${ }^{65}$ was of the view that in spite of all the complaints before the Cohen Committee which the committee found not to be unfounded, ${ }^{66}$ still came up with the Section 750.The current practice may well overtake or override the provisions of the Act, by the detailed inclusion of the powers and obligations of the trustee in the trust deed. The implication is that the detailed listing of the powers and duties of the trustees may well absolve them of any duty of care to the debenture holders.

\section{Conclusion}

Quite clearly, the standard of care and diligence expected of the trustee ought to be spelled out by legislation. This standard of care must be required both prior to and subsequent to the default.

The initial issue must however be resolved; this is the appointment and qualification of the trustees. Where the Law allows the basic qualification to be below the internationally acceptable standard, the duty of care is only limited to the competence of the trustee in his position and not on an objective assessment of who a trustee ought to be. It may be difficult to hold them to fulfill duties they are not equipped to handle, and should they slip below the required standard, to hold them fully liable. Yet on the other hand, to provide full protection someone must carry out those duties and the trustee is the only logical person to do so.

\footnotetext{
${ }^{61}$ Section 188(1) CAMA 2004.

${ }^{62}$ (1925) Ch. 407.

${ }^{63}$ See Section 88 .

${ }^{64}$ Great Britain Board of Trade, Committee on company Law amendment, para 61,

${ }^{65}$ Gower L.C.B. 1952. Modern Law Review. 52. 446 at 449-50.

${ }^{66}$ The Report of the Company Law committee (England) 1962, para 297.
} 